\title{
Effect of fuel utilization on the carbon monoxide poisoning dynamics of Polymer Electrolyte Membrane Fuel Cells
}

\author{
Luis C. Pérez ${ }^{a, b}$, Pauli Koski ${ }^{a}$, Jari Ihonen ${ }^{a}$, José M. Sousa ${ }^{b, c}$, Adélio Mendes ${ }^{b}$, \\ a VTT - Technical Research Centre of Finland, Biologinkuja 3-5, 02044 Espoo, Finland \\ b LEPABE - Laboratório de Engenharia de Processos, Ambiente, Biotecnologia e Energia, \\ Faculdade de Engenharia, Universidade do Porto, Rua Dr. Roberto Frias s/n, 4200-465 \\ Porto, Portugal \\ c Departamento de Química, Escola de Ciências da Vida e do Ambiente, Universidade de \\ Trás-os-Montes e Alto Douro, Apartado 1013, 5001-801 Vila-Real Codex, Portugal
}

\begin{abstract}
The effect of fuel utilization on the poisoning dynamics by carbon monoxide (CO) is studied for future automotive conditions of Polymer Electrolyte Membrane Fuel Cells (PEMFC). Three fuel utilizations are used, $70 \%, 40 \%$ and $25 \%$. CO is fed in a constant concentration mode of $1 \mathrm{ppm}$ and in a constant molar flow rate mode (CO concentrations between 0.18 and $0.57 \mathrm{ppm}$ ). The concentrations are estimated on a dry gas basis. The CO concentration of the anode exhaust gas is analyzed using gas chromatography. $\mathrm{CO}$ is detected in the anode exhaust gas almost immediately after it is added to the inlet gas. Moreover, the $\mathrm{CO}$ concentration of the anode exhaust gas increases with the fuel utilization for both $\mathrm{CO}$ feed modes. It is demonstrated that the lower the fuel utilization, the higher the molar flow rate of $\mathrm{CO}$ at the anode outlet at early stages of the $\mathrm{CO}$ poisoning. These results suggest that the effect of $\mathrm{CO}$ in PEMFC systems with anode gas recirculation is determined by the dynamics of its accumulation in the recirculation loop. Consequently, accurate quantification of impurities limits in current fuel specification (ISO 14687-2:2012) should be determined using anode gas recirculation.
\end{abstract}

\section{Introduction}

Prevailing heavy reliance on fossil fuels and increasing environmental concerns have raised interest in Polymer Electrolyte Membrane Fuel Cells (PEMFCs) for automotive applications [1]. The main technical problems of PEMFCs have been solved [2]; however, there is room to reduce costs and improve their durability $[3,4]$. One of the remaining 
issues is related to the presence of impurities in the fuel and/or the oxidant since they affect the performance and accelerate the degradation of PEMFCs [5].

PEMFC use hydrogen and oxygen in order to generate electricity and water, releasing heat [6]. While the oxidant composition is not currently regulated, the fuel composition is regulated according to standard ISO 14687-2:2012, which outlines the $\mathrm{H}_{2}$ fuel specification for road vehicles. This standard limits the amount of impurities such as carbon dioxide $\left(\mathrm{CO}_{2}\right)$ to $2 \mathrm{ppm}$, carbon monoxide (CO) to $0.2 \mathrm{ppm}$, ammonia $\left(\mathrm{NH}_{3}\right)$ to 0.1 ppm and sulfur species (e.g. $\mathrm{H}_{2} \mathrm{~S}$ and $\mathrm{SO}_{2}$ ) to $4 \mathrm{ppb}$.

Complying with the $\mathrm{H}_{2}$ fuel specification hinders the market growth of PEMFC vehicles due to the increased fuel costs. This is true especially for $\mathrm{H}_{2}$ that is produced via methane steam reforming (MSR) [7] and purified using pressure swing adsorption (PSA) [8] as it contains trace amounts of $\mathrm{CO}$. This latter $\mathrm{H}_{2}$ production process is considered to be the least expensive if methane is available at reasonable price. The increase in cost due to the use of PSA comes from the fact that the lower the level of impurities required, the lower the $\mathrm{H}_{2}$ yield of the PSA system. This is well illustrated in a paper by Besancon et al. [9].

$\mathrm{CO}$ is considered one of the most challenging impurities for two reasons. First, it is difficult to separate and to measure in a cost effective way at a concentration of 0.2 $\mathrm{ppm}$. Second, CO decreases the performance of PEMFCs as it preferentially adsorbs onto the anode catalyst, usually platinum $(\mathrm{Pt})$, hindering the hydrogen oxidation reaction (HOR). The last phenomenon is referred as "CO poisoning", and its short term effects are well documented [5]. However, there is a noticeable lack of information regarding the impact of $\mathrm{CO}$ in the durability of PEMFCs. Franco [10] has recently summarized the efforts made so far to predict the durability of PEMFCs. That author observed a decrease in the corrosion of cathode catalyst support in a long-term test (>600 h) when hydrogen with $5 \mathrm{ppm}$ CO was fed to a PEMFC with an anode catalyst loading $\approx 0.2 \mathrm{mg} \mathrm{Pt} \mathrm{cm}{ }^{-2}$ under load cycling conditions. Those results highlight the importance of studying the synergies between impurities and materials degradation in PEMFCs.

Despite great advances related to understanding CO poisoning, there are at least two issues that need to be studied with greater detail. The first issue is the CO poisoning dynamics, which is still poorly understood for low anode catalyst loadings, i.e. $<0.1 \mathrm{mg}$ $\mathrm{Pt} \mathrm{cm}{ }^{-2}$. According to Gasteiger et al. [11], only $0.05 \mathrm{mg} \mathrm{Pt} \mathrm{cm}^{-2}$ would be needed in the absence of impurities. Despite that, current membrane electrode assemblies (MEAs) for automotive PEMFC systems incorporate higher anode Pt loadings [12]. Hashimasa et al. [13] contributed to understanding the effect of catalyst loading on CO poisoning by testing anode Pt loadings between 0.05 and $0.4 \mathrm{mg} \mathrm{Pt} \mathrm{cm}^{-2}$. Those authors observed a slower decrease in performance at higher catalyst loadings for a constant CO concentration of $1 \mathrm{ppm}$. Furthermore, Angelo et al. used an anode Pt loading of $0.1 \mathrm{mg}$ $\mathrm{Pt} \mathrm{cm}{ }^{-2}$ and CO concentrations of $0.2 \mathrm{ppm}$ [14] and $1 \mathrm{ppm}$ [15] to study the steady state CO poisoning. Those authors observed a decrease in electrochemically active area of the anode after their tests. Despite the importance of catalyst loading on the CO poisoning 
of PEMFC, it is noted that the most relevant studies in the literature [16e19] have been

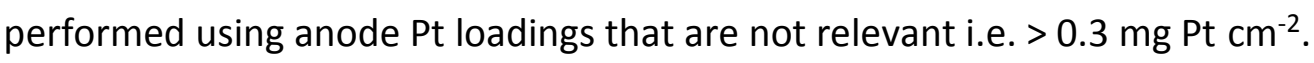

The second issue that must to be studied in greater detail is the effect of the $\mathrm{H}_{2}$ stoichiometric rate $\left(\lambda \mathrm{H}_{2}\right) \mathrm{P}$ or fuel utilization rate $(\mathrm{mf})$ on the $\mathrm{CO}$ poisoning. The $\mathrm{H}_{2}$ stoichiometric rate and the fuel utilization rate are related according to [6]:

$$
\lambda_{\mathrm{H}_{2}}=\frac{1}{\mu_{f}}
$$

It is observed that in most of the studies only one fuel utilization was used, i.e. 17\% [17], $50 \%[14,15,18-20]$ or $70 \%[13,21]$, not corresponding to actual PEMFC systems that may operate on a wide range of fuel utilizations $[4,22]$. The effect of fuel utilization on CO poisoning has been studied numerically for $C O$ concentrations $\geq 10 \mathrm{ppm}[16,23]$ and $\mathrm{CO}$ concentrations in the range 1-5 ppm [24]. The modeling results of Bonnet et al. [24] suggest that the current density, $\mathrm{CO}$ coverage and anode overpotential along the flow field is more homogeneous at lower fuel utilizations.

The most representative studies on CO poisoning have been performed using single cells for which the excess exhaust gas is vented to atmosphere [13-21]. Nevertheless, the CO poisoning dynamics is expected to be different in actual automotive PEMFC systems where the fuel is delivered in dead end mode with recirculation [25-29] (Fig. 1). Regarding the effect of impurities, the fuel delivery configuration depicted in Fig. 1 makes it necessary to study the buildup or enrichment of impurities in the recirculation loop [30-32]. The term enrichment of impurities is applied to reactive and/or nonreactive species other than $\mathrm{H}_{2}$ that may accumulate in the recirculation loop until they are vented to atmosphere. To the best knowledge of the authors, only Matsuda et al. [33] have experimentally studied the enrichment of impurities. However, in their work the anode catalyst loading was $0.4 \mathrm{mg} \mathrm{Pt} \mathrm{cm}^{-2}$ and the concentration of $\mathrm{CO} 4.8 \mathrm{ppm}$. Ahluwalia and Wang [30] have modeled the enrichment of $\mathrm{CO}$ and $\mathrm{CO}_{2}$. Those authors observed that the enrichment depends on the original $\mathrm{CO}$ concentration which can reach $175 \%$ and $600 \%$ of its original value at the stack inlet and outlet respectively.

Regarding the effect of fuel utilization, the fuel delivery configuration of Fig. 1 makes necessary to use high gas recirculation rates since recirculated gas is used to humidify the $\mathrm{H}_{2}$ at the anode inlet [29]. In this respect, there is a lack of literature documenting the effect of fuel utilization on the CO poisoning dynamics of PEMFC systems with anode gas recirculation.

It is of the utmost importance to analyze the composition of the anode recirculation gas in order to evaluate the enrichment of impurities in PEMFC systems. One approach to gain insight on the enrichment of impurities is to analyze the anode exhaust gas composition in single cells (fuel is fed and exhaust gas is vented). The latter has been applied in a few studies for CO [13-15,18,19,34-36], but again, the CO concentration, and/or the anode catalyst loading and/or the fuel utilization were too high in these studies. In a study by Pérez et al. [35] it was demonstrated that the fuel utilization 
influences the CO poisoning dynamics for CO concentrations between 15 and $19 \mathrm{ppm}$, fuel utilizations in the range $55 \mathrm{e} 83 \%$ and an anode catalyst loading of $0.4 \mathrm{mg} \mathrm{Pt} \mathrm{cm}{ }^{-2}$. In that study, due to the high Pt loading and fuel utilizations used, no significant amount of $\mathrm{CO}$ was detected in the anode exhaust gas before a significant drop in the current was observed. In contrast, in the studies by Hashimasa et al. [13] (1 ppm of CO, 0.05-0.4 mg

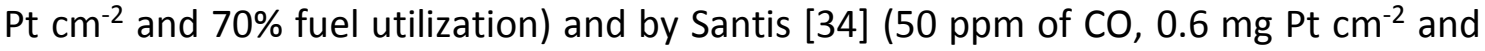
$50 \%$ fuel utilization), CO was detected for a marginal drop in performance during galvanostatic [13] and potentiostatic [34] operation.

Obtaining information about the anode exhaust gas composition and $\mathrm{CO}$ enrichment in the recirculation loop using low anode catalyst loadings $\left(<1 \mathrm{mgPtcm}^{-2}\right)$, low CO concentrations $(<1 \mathrm{ppm})$ and different fuel utilizations is of crucial importance to optimize the fuel quality for PEMFC vehicles. However, there are no experimental results in the literature with enough relevance for this purpose. In this paper, the influence of fuel utilization on the $\mathrm{CO}$ poisoning dynamics is studied in experimental conditions that are relevant to PEMFC vehicles. Three fuel utilizations namely, $70 \%, 40 \%$ and $25 \%$ are experimented. The $\mathrm{CO}$ is fed in a constant concentration mode of $1 \mathrm{ppm}$ and in a constant molar flow rate mode ( $\mathrm{CO}$ concentrations between 0.18 and $0.57 \mathrm{ppm}$ ). A single cell with an anode catalyst loading of $0.05 \mathrm{mg} \mathrm{Pt} \mathrm{cm}^{-2}$ is operated in galvano-static mode at $1 \mathrm{~A} \mathrm{~cm}^{-2}$ and $80^{\circ} \mathrm{C}$. The voltage drop is monitored while the CO concentration at the anode outlet is measured using gas chromatography (GC).

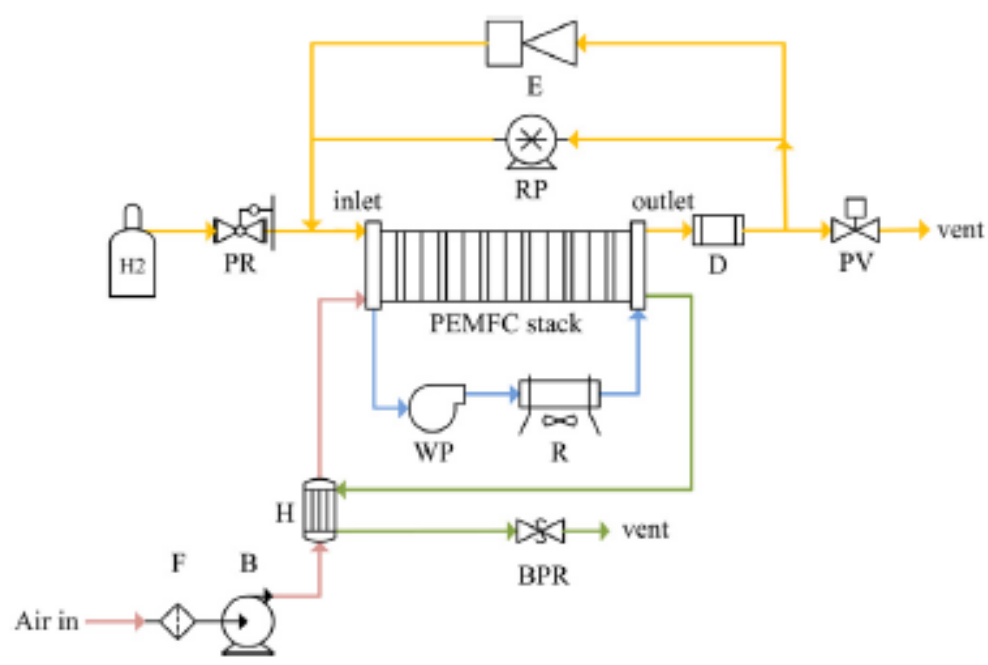

Fig. 1. Simplified diagram of an automotive PEMFC system. PR, pressure regulator; $D$, demister; PV, purge valve; RP, recirculation pump; $E$, ejector; $F$, filter; $B$, blower; $H$, humidifier; WP, water pump; R, radiator; BPR, back pressure regulator. Adapted from [22-25]. 


\section{Experimental}

\subsection{Test bench description}

The experiments were performed in a fuel cell test station (G60 series, Greenlight Innovation, Canada) with automated control and measurement of gases' flow rates, temperatures, dew points, pressures and electrochemical characterization of the cell.

Fig. 2 shows a schematic of the experimental set-up. The single cell (Fuel Cell Technologies Inc., USA) comprised a MEA (H series, Solvicore, Germany) with $25 \mathrm{~cm}^{2}$ active area loaded with $0.05 \mathrm{mg} \mathrm{Pt} \mathrm{cm}{ }^{-2}$ on the anode and with $0.4 \mathrm{mg} \mathrm{Pt} \mathrm{cm}{ }^{-2}$ on the cathode. The gas diffusion layers (Sigracet ${ }^{\circledR}$ SGL 24 BC, SGL technologies, Germany) were $235 \mathrm{~mm}$ thick. Teflon ${ }^{\circledR}$ gaskets with $150 \mathrm{~mm}$ thickness were used. The clamping pressure was regulated using disc springs (Belleville, UK).

The temperature of the cell was set to $353 \mathrm{~K}$ and measured with a thermocouple inserted inside the cathode bipolar plate. The bi-polar plates were manufactured from graphite blocks (ISEM-3, Svenska Tanso, Sweden) with $88 \mathrm{~mm}$ length $\times 88 \mathrm{~mm}$ width $\mathrm{x}$ $20 \mathrm{~mm}$ thick. Single channel serpentine flow fields were machined on both bipolar plates. The geometry of the gas channel was $1 \mathrm{~mm}$ width $\times 1.5 \mathrm{~mm}$ depth, while the rib was $1 \mathrm{~mm}$ width. The gases were fed in counter-flow.

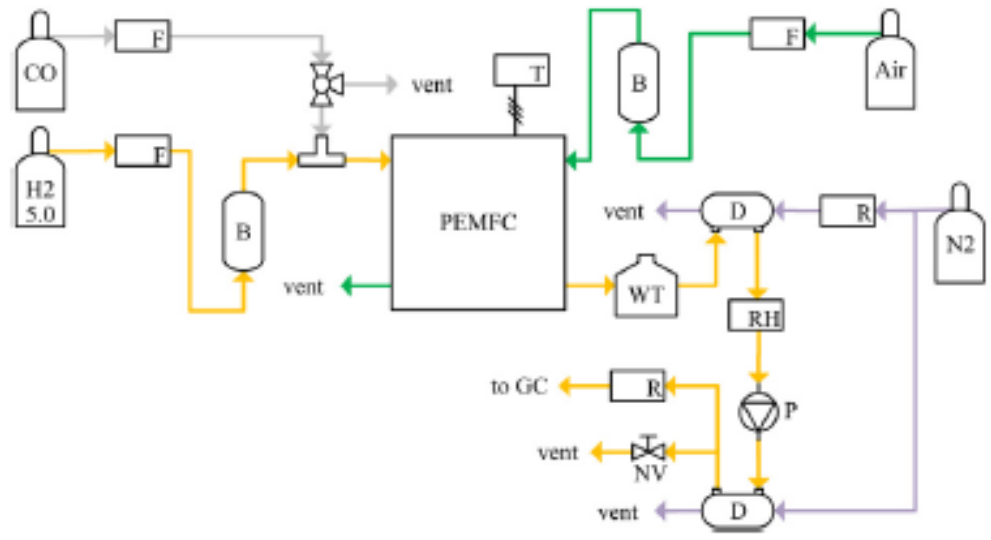

Fig. 2. Schematic of the experimental set-up. $F$, mass flow controller; B: bubbler, $T$ : thermocouple, WT: water trap, $\mathrm{D}$, dryer; $\mathrm{R}$, rotameter; $\mathrm{RH}$, relative humidity probe; $\mathrm{P}$, diaphragm pump and $\mathrm{NV}$, needle valve

\subsubsection{Anode feed and conditioning of exhaust gas}

The anode was fed with $\mathrm{H}_{2}$ (99.999\% pure, amount of impurities: $\mathrm{H} 2 \mathrm{O} \leq 3 p p m \mathrm{O}_{2} \leq 2 \mathrm{ppm}$ $\mathrm{C}_{\mathrm{n}} \mathrm{H}_{\mathrm{m}} \leq 0.5 \mathrm{ppm}$ and $\mathrm{N}_{2} \leq 5 \mathrm{ppm}$ ) at three fuel utilizations, $\mathrm{mf} 1 / 470 \%, 40 \%$ and $25 \%$. The anode dew point was $336.85 \mathrm{~K}$, so the anode relative humidity $\left(\mathrm{RH}_{\text {ano }}\right)$ at the inlet was $50 \%$. The anode pressure $\left(\mathrm{P}_{\text {ano }}\right)$ was atmospheric. The CO was obtained from a 150 bar 
gas bottle (AGA OY, Finland) with a nominal concentration of $\mathrm{CO}\left(\mathrm{C}_{\mathrm{CO}}\right)$ of $90.9 \mathrm{ppm}$ balanced with $\mathrm{N}_{2}$.

The anode exhaust gas was conditioned to ensure minimal dissolution of $\mathrm{CO}$ into water. A water trap located immediately at the anode outlet separated the water from the hot and humid exhaust gas. The gas was then dried using a selective membrane module (FC'M -Series, Perma Pure LLC, USA). Dry nitrogen $\left(\mathrm{N}_{2}\right)$ was fed to the permeate side of the membrane module in counter current at a volumetric flow rate of $Q_{\mathrm{N} 2}=1 \mathrm{dm}^{3} \mathrm{~min}^{-1}$ using a rotameter (UK-040 series, Honsberg, Germany). The relative humidity and temperature of the gas was measured after the membrane module with a probe model HMP110 (Vaisala, Finland). The average temperature and dew point of the exhaust gas at this point were $300 \mathrm{~K}$ and $265 \mathrm{~K}$ respectively, corresponding to a vapor pressure of $0.0003354 \mathrm{MPa}$.

A micro diaphragm pump (NMS 020 B, KNF, Germany) was used to minimize the delay between the anode outlet and the chromatograph. To remove the remaining water, $a$ second membrane module (FC - Series, Permapure LLC, USA) was placed after the pump to further dry the sample by feeding $\mathrm{N}_{2}$ in counter flow as detailed above. A needle valve (Series AS, SMC, Japan) was used to control the amount of gas sent to the chromatograph while a rotameter (FLD series, Omega, USA) measured the flow rate of the sample.

\subsubsection{Cathode feed}

The cathode was fed with humidified synthetic air. The oxidant utilization $\left(\mu_{\mathrm{ox}}\right)$ was $40 \%$ in all the experiments. The cathode dew point was $336.85 \mathrm{~K}$ so the cathode relative humidity $\left(\mathrm{RH}_{\mathrm{cat}}\right)$ at the inlet was $50 \%$. The cathode pressure $\left(\mathrm{P}_{\text {cat }}\right)$ was atmospheric. The amount of $\mathrm{CO}_{2}$ in the synthetic air was measured using $\mathrm{GC}(230 \mathrm{ppm})$.

\subsection{Gas chromatograph description}

The gas chromatograph (model 6890N, Agilent Technologies, USA) was equipped with a flame ionization detector (FID) for $\mathrm{CO}$ and $\mathrm{CO}_{2}$ detection. The equipment was calibrated daily using a gas mixture supplied from a 150 bar gas bottle (AGA OY, Finland) with a nominal $\mathrm{CCO}$ of $10.2 \mathrm{ppm}$ and a nominal $\mathrm{CO}_{2}$ concentration $\left(\mathrm{CCO}_{2}\right)$ of $9.63 \mathrm{ppm}$ balanced with He. The chromatograph was programmed to take a gas sample, plot the corresponding chromatogram and record it in a file. This process took approximately 4 min, so 16 gas samples were automatically taken every hour.

Compared to our previous study [35], the chromatograph was improved for detecting lower $\mathrm{CO}$ levels. The single column configuration used previously was changed to a configuration with two columns, one to detect $\mathrm{CO}$ and the other for the $\mathrm{CO}_{2}$. This eliminated disturbances attributed to a marginal contamination of the sample $\left(\mathrm{N}_{2}\right.$ or 
$\mathrm{H}_{2} \mathrm{O}$ ), which made it very hard to find a clear point to start integrating the $\mathrm{CO}$ peak and thus determine more accurately the $\mathrm{CO}$ concentration.

The chromatograph signal processing was also improved compared to previous study [35]. Briefly, the signals were processed using a Matlab® routine that integrated the $\mathrm{CO}$ peak using a trapezoidal algorithm and a noise filter after careful selection of the integration limits. For this work, a linear least squares fitting was used to minimize the marginal fluctuation of the baseline.

\subsection{Test procedure}

Table 1 summarizes the experiments performed. Different CO feed regimes were used. In Experiments \#1 to \#3 a constant CCO of 1 ppm was used. During Experiments \#4, \#5 and $\# 6$ the molar flow rate of $\mathrm{CO}$ at the anode inlet $\left(\dot{n}_{\mathrm{CO}}\right.$, in $)$ was $1.87 \times 10^{-10} \mathrm{~mol} \mathrm{~s}^{-1}$ and for Experiments \#7, \#8 and \#9 was halved to $0.93 \times 10^{-10} \mathrm{~mol} \mathrm{~s}^{-1}$. The experiments were repeated at least four times and their reproducibility assessed. The cell was activated using an in-house developed potentiostatic cycling protocol. Every experiment star-ted with a stabilization period of at least $1 \mathrm{~h}$ during which the cell was operated with the conditions of interest but without feeding CO. After this, $\mathrm{CO}$ was fed until a potential drop of $50 \mathrm{mV}$ was reached and then stopped.

Table 1. Details of experimental conditions

\begin{tabular}{|c|c|c|c|c|c|c|c|}
\hline Exp.\# & $T_{\text {cell }}(K)$ & $H_{f}(\%)$ & $\mathrm{C}_{\mathrm{co}}(\mathrm{ppm})$ & $\mathrm{ItCO}_{\mathrm{CO}}\left(\times 10^{-10} \mathrm{~mol} \mathrm{~s}^{-1}\right)$ & $\mu_{a x}(\%)$ & $R H_{\text {ano }}=R H_{\text {cat }}(\%)$ & $P_{2 n o}=P_{c a t}(M P a)$ \\
\hline 1 & 353.15 & 70 & 1 & 1.87 & 40 & 50 & $\approx 0.101$ \\
\hline 2 & & 40 & & 3.27 & & & \\
\hline 3 & & 25 & & 5.24 & & & \\
\hline 4 & & 70 & & 1.87 & & & \\
\hline 5 & & 40 & 0.57 & & & & \\
\hline 6 & & 25 & 0.36 & & & & \\
\hline 7 & & 70 & 0.50 & 0.93 & & & \\
\hline 8 & & 40 & 0.28 & & & & \\
\hline 9 & & 25 & 0.18 & & & & \\
\hline
\end{tabular}

A procedure to clean the anode catalyst surface was applied between measurements. The procedure intended to promote the electrooxidation of $\mathrm{CO}$ [35], remove the CO from the anode catalyst surface and start every experiment with the same amount of anode catalytic sites available. The procedure included three steps: i) substitution of $\mathrm{H}_{2}$ by $\mathrm{N}_{2}$ with galvanostatic operation of the cell at $I_{\text {tot }}=1.5$ An until $E_{\text {cell }}=0.6 \mathrm{~V}$, ii) potentiostatic operation of the cell at $\mathrm{E}_{\text {cell }}=0.6 \mathrm{~V}$ until $\mathrm{I}_{\text {tot }}=0.150 \mathrm{~A}$ and iii) potentiostatic operation of the cell at $\mathrm{E}_{\text {cell }}=0.1 \mathrm{~V}$ until $\mathrm{I}_{\text {tot }} \approx 0 \mathrm{~A}$.

The $\mathrm{CO}$ concentrations of Table 1 are given on a dry gas basis. The $\mathrm{H}_{2}$ fuel specifications, the standards ISO 14687-2:2012 and ISO/DIS 14687-3 (under development), outline the concentration limit for different impurities on a dry gas basis, so it is a common practice 
of PEMFC impurities research groups to do it accordingly [19,35,37-39]. Concentrations in the wet gas basis vary by a constant factor depending on the relative humidity at the anode inlet of each test. Due to the latter, the wet gas basis in PEMFC impurities research is not reported. The methodology to determine the dry gas basis CO concentrations of Table 1 is described in detail below. The corresponding wet gas basis concentrations are shown in Appendix 1.

The molar flow rate of $\mathrm{CO}$ at the anode outlet, $\dot{n}_{\mathrm{CO}}$, out $\left(\mathrm{mol} \mathrm{s}^{-1}\right)$, was calculated using Equation (2). The volumetric flow rate of the gas mixture leaving the cell (dry basis), Qout $\left(\mathrm{cm}^{3} \mathrm{~s}^{-1}\right)$, was calculated considering the volumetric flow rate of hydrogen fed to the anode, $Q_{\mathrm{H} 2}\left(\mathrm{~cm}^{3} \mathrm{~s}^{-1}\right)$, the volumetric flow rate of nitrogen from the impurity balance gas, $Q_{N 2, \text { bal }}\left(\mathrm{cm}^{3} \mathrm{~s}^{-1}\right)$ and the hydrogen consumed, $Q_{\mathrm{H} 2}$, cons $\left(\mathrm{cm}^{3} \mathrm{~s}^{-1}\right)$, assuming $100 \%$ of coulombic efficiency, according to Equations (3)-(6) as follows:

$$
\begin{aligned}
& \dot{n}_{\text {CO,out }}=\frac{Q_{\text {out }} \times C_{\mathrm{CO}, \text { out }} \times P}{R T} \\
& Q_{\text {out }}=Q_{\mathrm{H}_{2}}+Q_{\mathrm{N}_{2} \text {, bal }}-Q_{\mathrm{H}_{2}, \text { cons }} \\
& Q_{\mathrm{H}_{2}}=\dot{n}_{\mathrm{H}_{2}} R \frac{T}{P} \frac{1}{\mu_{f}} \\
& \dot{n}_{\mathrm{H}_{2}}=\frac{I_{\text {tot }}}{2 F} \\
& Q_{\mathrm{H}_{2}, \text { cons }}=\frac{I_{\text {tot }} R T}{2 F P}
\end{aligned}
$$

where, $\mathrm{C}_{\mathrm{co} \text {,out }}(\mathrm{ppm})$ is the $\mathrm{CO}$ concentration (dry basis), $\mathrm{P}(\mathrm{Pa})$ is the pressure, $\mathrm{R}$ is the gas constant, $8.314 \mathrm{~J} \mathrm{~mol}^{-1} \mathrm{~K}^{-1}, \mathrm{~T}(\mathrm{~K})$ is the temperature, $\dot{n}_{\mathrm{H} 2}\left(\mathrm{~mol} \mathrm{~s}^{-1}\right)$ is the molar flow rate of hydrogen fed to the anode, $I_{\text {tot }}(A)$ is the current of the cell and $F$ is the Faraday constant, $96485.34 \mathrm{C} \mathrm{mol}^{-1}$.

\section{Results and discussion}

The sources of error and other factors affecting the $\mathrm{CO}$ and $\mathrm{CO}_{2}$ concentration measurements during $\mathrm{CO}$ poisoning of PEMFCs have been properly identified previously $[18,35]$. Here, those sources of error were taken into consideration. Furthermore, the high purity $\mathrm{H} 2$ was analyzed for several hours with the chromatograph in order to detect possible traces of $\mathrm{CO}$. The amount of $\mathrm{CO}$ in the high purity $\mathrm{H}_{2}$ was $\approx 35 \mathrm{ppb}$, so that value was used to correct the $\mathrm{CO}$ concentrations.

Before evaluating the effect of fuel utilization at $\mathrm{CO}$ concentrations below $1 \mathrm{ppm}$, it was necessary to assess the reproducibility of the tests. The latter is highlighted in Fig. 3 for 
Experiment \#1 with three repetitions, all performed consecutively. The reproducibility was evaluated from two perspectives: i) the potential drop curves (Fig. 3a), which is related to the time needed to reach the $50 \mathrm{mV}$ potential drop and ii) the anode exhaust gas composition analysis, which is related to the CO concentration (Fig. $3 \mathrm{~b}$ ) and the $\mathrm{CO}$ molar flow rate (Fig. $3 \mathrm{c}$ ) at the anode outlet. It is observed that the results depicted in Fig. 3 are reproducible and consistent. The same reproducibility and consistency was observed for the rest of the experiments.

One key issue for achieving the excellent reproducibility and consistency of the results shown in Fig. 3 was the procedure implemented to clean the anode catalyst surface. A positive effect of the procedure on the reproducibility of the results was observed until the effect of catalyst aging was noticeable (Section 3.3).

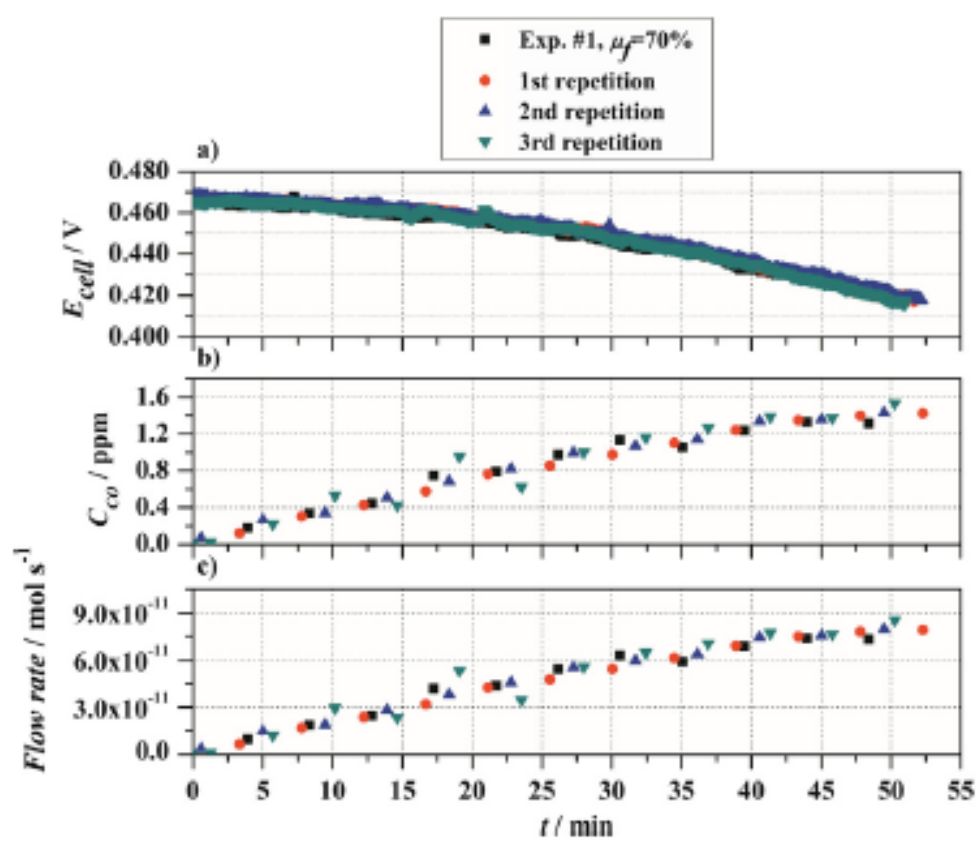

Fig. 3. Performance of the fuel cell for $\mu_{\mathrm{f}}=70 \%$ and 1 ppm CO feed (Experiment \#1); a) potential drop history, b) CO concentration (dry basis) at the anode outlet as a function of time and c) estimated molar flow rate of $\mathrm{CO}$ at the anode outlet as a function of time. The $\mathrm{CO}$ is injected at $\mathrm{t} 1 / 40 \mathrm{~min}$. Other experimental conditions in Table 1.

\subsection{Effect of fuel utilization for a constant CO feed concentration of $1 \mathrm{ppm}$}

The measurements with constant concentration and varying fuel utilization rate do not correspond to any real situation of automotive PEMFC systems. It is, however, important to study the effect of fuel utilization at a constant $\mathrm{CO}$ concentration in order to make literature data easy to compare. Another reason to study this topic was to support the 
DuraDemo project [40] in which low fuel utilization without fuel recirculation is used and the anode exhaust gas is used to generate steam for a power plant.

Fig. 4 shows the potential drop, $\mathrm{CO}$ concentrations and $\mathrm{CO}$ molar flow rates at the anode outlet for a constant $1 \mathrm{ppm}$ CO concentration at the inlet. A single test with no repetitions was plotted for each experiment. Fig. 4a shows that it took approximately $10 \mathrm{~min}$ more to reach the potential drop of $50 \mathrm{mV}$ for the lowest fuel utilization when compared to the highest fuel utilization despite the fact that the molar flow rate of CO was $\approx 3$ times higher in the former case (Table 1 ). The potential drop was attributed to the adsorption of $\mathrm{CO}$ onto the anode catalytic sites. The results of Fig. 4 a seem to be counterintuitive once it would be expected a faster drop in performance for a higher CO molar feed. The results, however, can be explained with the anode exhaust gas composition analysis.

Fig. $4 \mathrm{~b}$ shows that the $\mathrm{CO}$ concentration at the outlet exceeded the $1 \mathrm{ppm}$ CO concentration at the inlet for the $70 \%$ fuel utilization after 27.5 min but stayed under 1 ppm for the cases with $40 \%$ and $25 \%$ fuel utilization. The CO concentration may increase or decrease along the flow field channels in a PEMFC fed with CO. The CO concentration decreases due to: $\mathrm{i}$ ) the adsorption of $\mathrm{CO}$ onto the catalyst and ii) the oxidation of $\mathrm{CO}$ by the $\mathrm{O}_{2}$ permeating from the cathode, what is called internal air bleed [41]. The CO concentration increases since $\mathrm{H}_{2}$ is consumed along the flow field channels [13].In addition, any increase in the vapor pressure along the flow field will have a diluting effect; however, this depends on the water balance of the cell. In our case, the increase in $\mathrm{CO}$ concentration at the end of the experiments suggests that the system did not reach steady state during the experiments.

The faster decrease in performance for the highest fuel utilization observed in Fig. 4 is then explained by the increase in the CO concentration towards the outlet of the cell, which is higher at higher fuel utilizations. The dynamic nature of the $\mathrm{CO}$ poisoning phenomena at early stages has been studied numerically by several groups [42-45]. The study of Zamel and Li [45] indicate that the fraction of catalytic sites covered by $\mathrm{CO}$ increases faster at higher CO concentrations, resulting in a faster decrease in performance of the cell.

Fig. 4c shows that the lower the fuel utilization, the higher the molar flow rate of $\mathrm{CO}$ at the anode outlet for a constant CO con-centration at the inlet. Moreover, it is observed that the molar flow rate of $\mathrm{CO}$ at the anode outlet increases more steeply after $\mathrm{CO}$ is first fed at lower fuel utilizations. The molar flow rates of $\mathrm{CO}$ at the anode inlet are highlighted on the right $Y$ axis of the same figure. Those values were used to calculate the ratio between the molar flow rate of $\mathrm{CO}$ at the anode outlet and inlet. By the end of the experiments, the ratios were $64 \%$ for $\mu \mathrm{f}=25 \%, 49 \%$ for $\mu \mathrm{f}=40 \%$ and $48 \%$ for $\mu \mathrm{f}=$ $70 \%$. These ratios demonstrate that the proportion of $\mathrm{CO}$ that leaves the cell without being adsorbed onto the anode catalyst or oxidized to $\mathrm{CO}_{2}$ due to the internal air bleed is higher at lower fuel utilizations for a constant $\mathrm{CO}$ concentration at the anode inlet. 


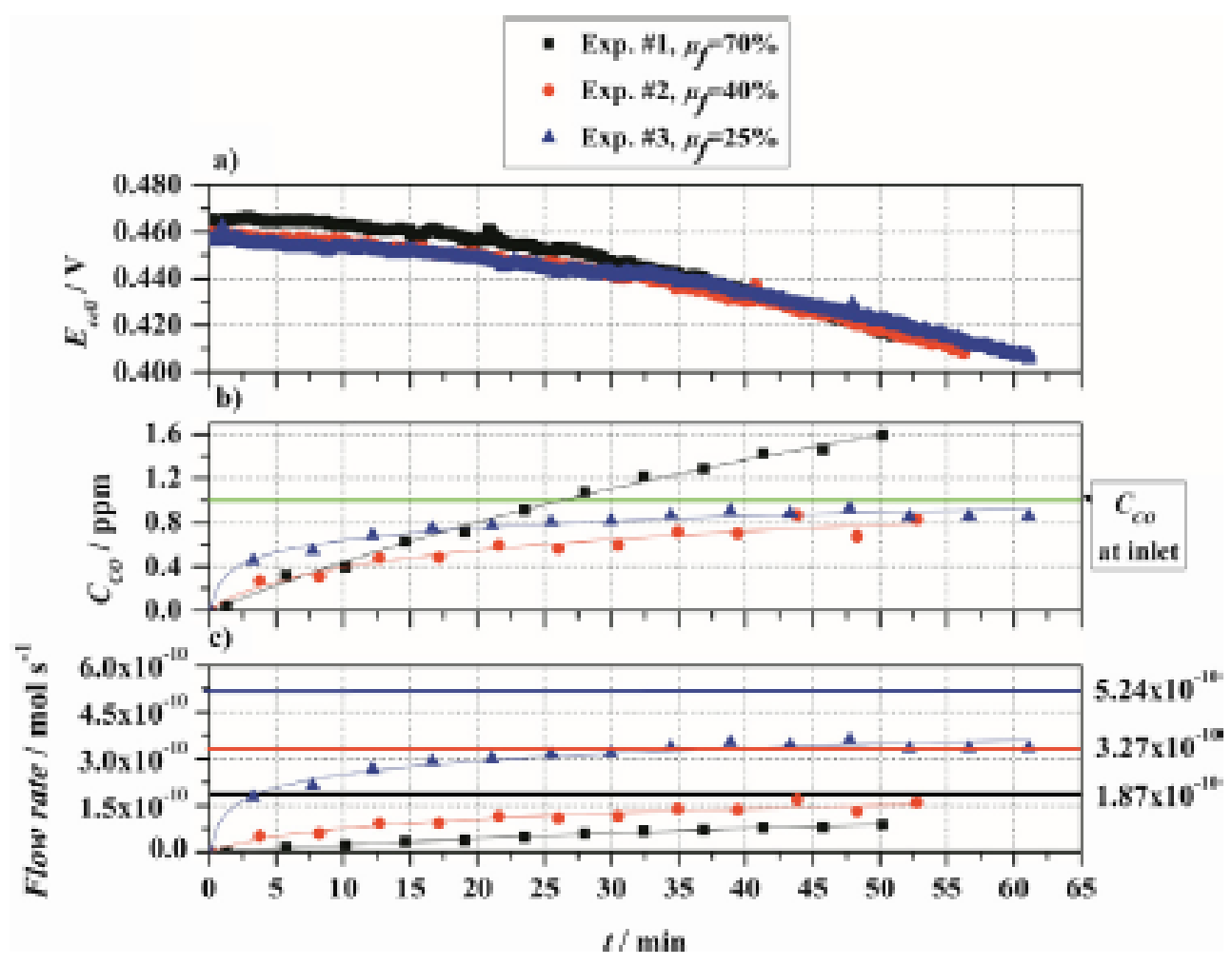

Fig. 4. Performance of the fuel cell for $\mu f=70 \%$ (Experiment \#1), $\mu f=40 \%$ (\#2) and $\mu f$ $=25 \%$ (\#3) and 1 ppm CO feed: a) potential drop history, b) CO concentration (dry basis) at the anode outlet as a function of time and c) estimated molar flow rate of $\mathrm{CO}$ at the anode outlet as a function of time. The $\mathrm{Y}$ axis on the right of Fig. $4 \mathrm{c}$ is the corresponding molar flow rate of $\mathrm{CO}$ at the anode inlet. The $\mathrm{CO}$ is injected at $\mathrm{t}=0 \mathrm{~min}$. Other experimental conditions in Table 1.

\subsection{Effect of fuel utilization for a low constant $\mathrm{CO}$ molar flow rate}

The measurements of the following sections correspond to actual automotive PEMFC applications for which the total amount of $\mathrm{CO}$ fed to the cell is the same for the same period of time. Fig. 5 shows the potential drop, $\mathrm{CO}$ concentrations and $\mathrm{CO}$ molar flow rates at the anode outlet for a constant $\mathrm{CO}$ molar flow rate at the anode inlet of $1.87 \times 10^{-10} \mathrm{~mol} \mathrm{~s}^{-1}$. It can be observed that at lower fuel utilizations more time is needed to reach the $50 \mathrm{mV}$ potential drop (Fig. 5a). Furthermore, the time needed to reach the $50 \mathrm{mV}$ potential drop is five times higher for the lowest fuel utilization compared to the highest fuel utilization. The results of Figs. $4 a$ and $5 a$ demonstrate that the fuel utilization influences the $\mathrm{CO}$ poisoning dynamics for both a constant $\mathrm{CO}$ concentration and a constant $\mathrm{CO}$ molar flow feed.

Fig. $5 \mathrm{~b}$ shows that $\mathrm{CO}$ can be detected in the anode exhaust gas almost immediately after it is added to the inlet gas. In automotive PEMFC systems operating with anode gas recirculation, this would mean immediate start of the $\mathrm{CO}$ enrichment in the anode gas recirculation loop. 
Fig. $5 \mathrm{c}$ shows that the $\mathrm{CO}$ molar flow rate at the anode outlet reached a constant value fastest for the lowest fuel utilization. The latter, together with the results of Fig. 5a, indicate a compromise between the impurity enrichment and the drop in performance of the cell which was the slowest for the lowest fuel utilization.

If the total amount of $\mathrm{CO}$ fed to the cell is the same for the three experiments until $\mathrm{t} 1 / 4$ $27.5 \mathrm{~min}$, why the one with higher fuel utilization showed the fastest decrease in performance in Fig. 5? As in the case with constant $\mathrm{CO}$ concentration at the inlet, it is expected that the CO concentration increases towards the outlet of the cell more steeply at higher fuel utilizations leading to a faster decrease in performance of the cell. The last is further supported by the fact that the lower the fuel utilization the lower the amount of $\mathrm{CO}$ that was either adsorbed onto the anode catalyst or oxidized to $\mathrm{CO}_{2}$ by the internal air bleed until $\mathrm{t}=\mathbf{2 7 . 5} \mathrm{min}$, as showed in Fig. $5 \mathrm{c}$.

The results of Fig. 5 may provide insight regarding the effect of fuel utilization on the CO distribution profile within the cell. The distribution of $\mathrm{CO}$ within the cell has been studied both experimentally $[20,23,35,46]$ and numerically $[23,24]$. The numeric study by Bonnet et al. [24] shows the effect of $\mathrm{CO}$ on the current density distribution, the fraction of catalytic sites covered by $\mathrm{CO}$ and the anode overpotential. Those authors observed that the fraction of catalytic sites covered by $\mathrm{CO}$ close to the outlet is higher at higher fuel utilizations in steady state. However, the study by Brett et al.[23] shows the opposite, this is, that the fraction of catalytic sites covered by $\mathrm{CO}$ is higher close to the inlet at higher fuel utilizations.

It is important to highlight that modeling results by Bonnet et al.[24] are not in accordance with the experimental results of other authors $[20,35,46]$ who used a segmented PEMFC [47] and observed a lower current density close to the inlet for similar fuel utilizations. More experimental work is needed in order to analyze the effect of fuel utilization on the distribution of $\mathrm{CO}$ within the cell. However, the results presented here support the hypothesis that the factor dominating the distribution of $\mathrm{CO}$ within the cell is the mean gas velocity at the anode inlet, as observed by Brett et al. [23]. 


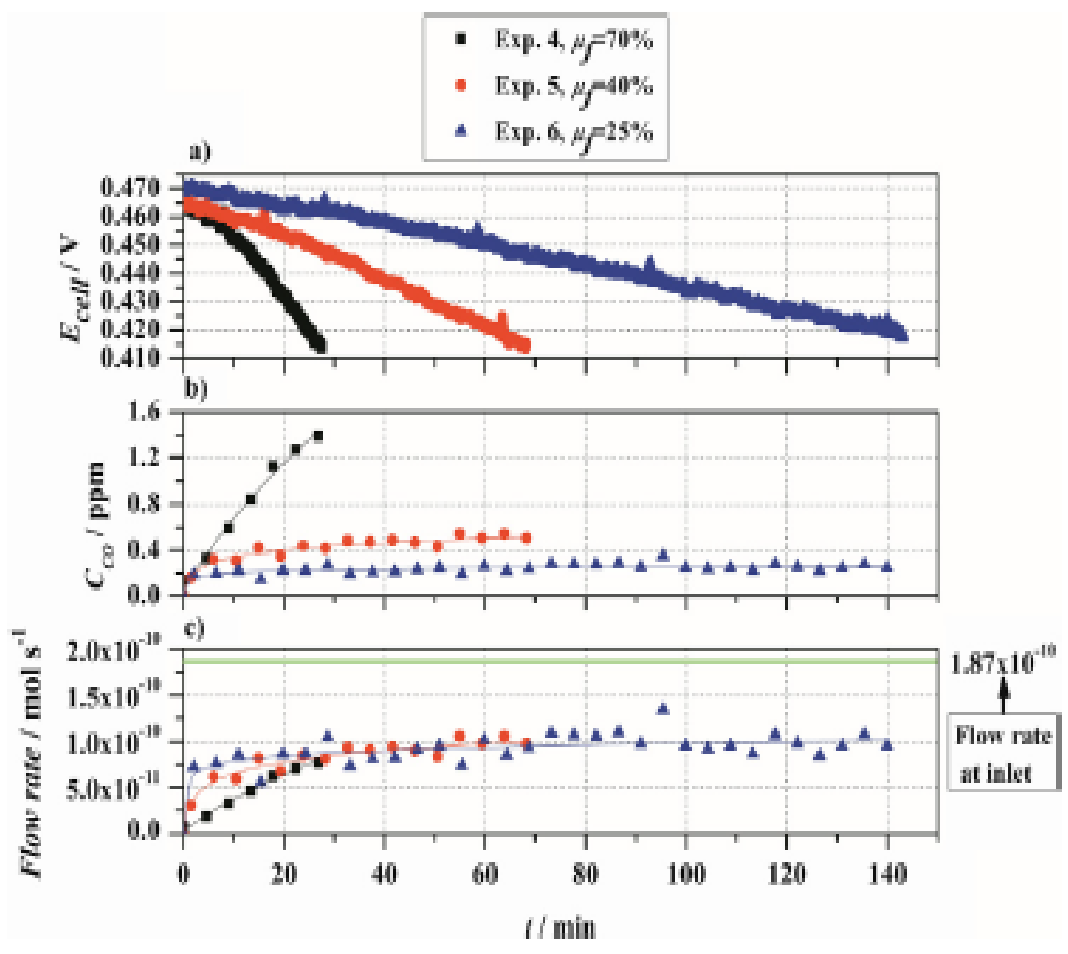

Fig. 5. Performance of the fuel cell for $\mu f=70 \%$ (Experiment \#4), $\mu f=40 \%(\# 5)$ and $\mu f=25 \%$ (\#6) and molar flow rate of $\mathrm{CO}$ at inlet of $1.87 \times 10^{-10} \mathrm{~mol} \mathrm{~s}^{-1}$; a) potential drop history, b) CO concentration (dry basis) at the anode outlet as a function of time; and c) estimated molar flow rate of $\mathrm{CO}$ at the anode outlet as a function of time. The $\mathrm{CO}$ is injected at $\mathrm{t}=0 \mathrm{~min}$. Other experimental conditions in Table 1.

\subsection{Effect of fuel utilization for an ultra-low constant $\mathrm{CO}$ molar flow rate}

Fig. 6 shows the potential drop, $\mathrm{CO}$ concentrations and $\mathrm{CO}$ molar flow rates at the anode outlet for a constant CO molar flow rate of $0.93 \times 10^{-10} \mathrm{~mol} \mathrm{~s}^{-1}$ at the anode inlet, which was $\approx 50 \%$ of the CO molar flow rate of Section 3.2. It is observed that the time needed to reach the $50 \mathrm{mV}$ potential drop is seven times higher for the lowest fuel utilization compared with the highest fuel utilization (Fig. 6a). When comparing Figs. 5a and 6a, it can be observed that the time needed to reach the $50 \mathrm{mV}$ potential drop increased $\approx 2$ times for the same fuel utilizations in accordance with the $\mathrm{CO}$ molar flow rate reduction.

Fig. 6a shows that in Experiment \#8 ( $\mu \mathrm{f}=40 \%)$ the onset potential started approx. 20 $\mathrm{mV}$ lower than for the other two Experiments (\#7 and \#9). Experiment \#8 (which comprises at least three repetitions) was the last to be performed, so the difference may highlight the aging of the anode catalyst. A loss of electrochemically active area has been reported at the anode after consecutive CO poisoning and recovery cycles [14]. The catalyst aging can be monitored using cyclic voltammetry [48] but in the current experimental set-up this was not possible. In the same way, it is important to account for the MEA degradation which is not associated to the CO poisoning [19] for a more 
accurate comparison of the results. Here, aging of the MEA may have been accelerated by the clean-up procedure and this adds some uncertainty to the results.

Fig. $6 \mathrm{~b}$ and $\mathrm{c}$ shows how it becomes difficult to accurately measure the $\mathrm{CO}$ concentration and determine the molar flow rate of $\mathrm{CO}$ at the anode outlet for Experiments \#8 and \#9. In these experiments the $\mathrm{CO}$ concentration at the inlet was $0.28 \mathrm{ppm}$ and $0.18 \mathrm{ppm}$ respectively. The fluctuations observed were attributed to current configuration of the chromatograph, which would need further optimization for these low concentrations. Despite the noise, the results of Fig. $6 \mathrm{~b}$ and $\mathrm{c}$ are in accordance with those observed in the previous Section (Fig. $5 b$ and c). The results show that less $\mathrm{CO}, \approx 35 \%$ of the molar flow rate at the inlet, can be detected at the exhaust gas compared to $\approx 55 \%$ for concentrations 2 times higher (Sections 3.2).

Experiment \#9 of Fig. 6 is close to the current $\mathrm{H} 2$ fuel specification for road vehicles (ISO 14687-2:2012) concerning the CO concentration limit of $0.2 \mathrm{ppm}$. It took approximately $5.5 \mathrm{~h}$ to reach the $50 \mathrm{mV}$ potential drop for this case. The conditions of the test, particularly the constant current density of $1 \mathrm{~A} \mathrm{~cm}^{2}$ and the $5.5 \mathrm{~h}$ length, will not correspond to the conditions demanded from an automotive PEMFC system since at full power (considering a 80-100 kW PEMFC stack) a 5-6 kg $\mathrm{H}_{2}$ tank is emptied in little more than an hour. The test neither included load cycles, which are important to study due to the transient nature of automotive PEMFC systems and especially because CO may mitigate corrosion of the cathode catalyst support and thus enhance MEA durability in the long term, as suggested elsewhere [49]. Despite that, the possibility of CO enrichment in the anode recirculation loop indicates the importance of its systematic study and evaluation of its implications on the regulation. This kind of systematic study may ultimately lead to the develop principles of safety engineering [50] aiming to reduce the risk and uncertainty associated to the presence of impurities in the $\mathrm{H}_{2}$ fuel. 


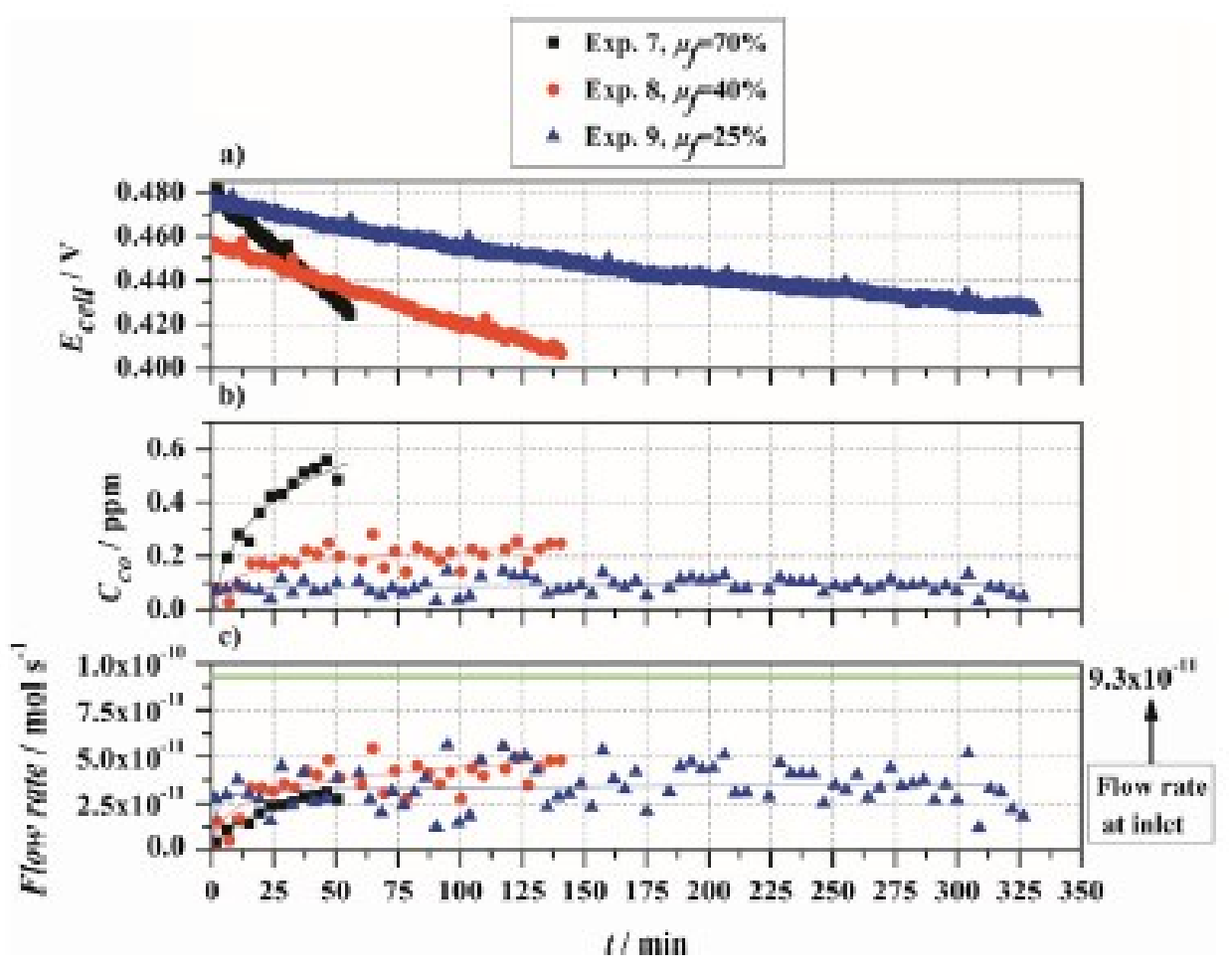

Fig. 6. Performance of the fuel cell for $\mu f=70 \%$ (Experiment \#7), $\mu f=40 \%$ (\#8) and $\mu f=$ $25 \%$ (\#9) and molar flow rate of $\mathrm{CO}$ at inlet of $0.93 \times 10^{-10} \mathrm{~mol} \mathrm{~s}^{-1}$; a) potential drop history; b) CO concentration (dry basis) at the anode inlet as a function of time; and c) estimated molar flow rate of $\mathrm{CO}$ at the anode outlet as a function of time. $\mathrm{CO}$ is injected at $\mathrm{t}=0$ min. Other experimental conditions in Table 1.

\section{Conclusions}

The CO poisoning dynamics of the anode catalyst was studied for CO concentrations between 0.18 and $1 \mathrm{ppm}$ and three fuel utilizations, $70 \%, 40 \%$ and $25 \%$ in a single cell. CO was fed either in a constant concentration or in a constant molar flow rate mode. The CO concentration at the anode outlet was measured using a gas chromatograph.

In all the experiments, CO was detected almost immediately in the anode exhaust gas after it was added to the anode inlet. This indicates that CO enrichment in PEMFC systems with fuel recirculation starts almost immediately. It was found that the increase in the $\mathrm{CO}$ concentration and $\mathrm{CO}$ molar flow rate in the anode exhaust gas were dependent on the fuel utilization and independent of the $\mathrm{CO}$ feed mode. The lower the fuel utilization, the faster it was the increase in the $\mathrm{CO}$ molar flow rate at the anode outlet.

It was demonstrated that the fuel utilization strongly influences the $\mathrm{CO}$ poisoning dynamics of PEMFCs independently of the $\mathrm{CO}$ feed mode used. For lower fuel utilizations the decrease in performance of the cell was slower. 
The slower decrease in performance at lower fuel utilizations is presumably due to lower fraction of catalytic sites covered by $\mathrm{CO}$, as $\mathrm{CO}$ coverage depends on the concentration. Moreover, it is suggested that at lower fuel utilizations the distribution of $\mathrm{CO}$ within the cell may be more homogeneous, facilitating the internal air bleed. However to confirm this it would be necessary measuring the distribution of $\mathrm{CO}$ within the cell and a detailed mass balance for $\mathrm{CO}$ and $\mathrm{CO}_{2}$.

The results indicate that impurities may accumulate in the anode loop of PEMFCs systems with fuel recirculation. Consequently, the accumulation dynamics will determine the effect of impurities at low concentration levels. This means that accurate determination of impurity limits for the ISO 14687-2:2012 standard makes necessary the use of fuel recirculation systems to study the anode catalyst poisoning of PEMFCs.

\section{Acknowledgments}

This research has been conducted under the "Fuel Cell 2007-2013" technology program of Tekes, the Finnish Funding Agency for Technology and Innovation.

L.C. Pérez is grateful to the National Foundation of Science and Technology of Portugal (FCT) for his PhD grant reference SFRH/BD/ 44684/2008. L. C. Pérez also acknowledges the support from the National Council of Science and Technology of Mexico (CONACyT).

\section{Appendix A. Supplementary data}

Supplementary data related to this article can be found at http://dx.doi.org/10.1016/i.jpowsour.2014.02.016.

\section{References}

[1] A.L. Dicks, in: A. Sayigh (Ed.), Comprehensive Renewable Energy, Elsevier, Oxford, 2012, pp. 203-245.

[2] Y. Wang, K.S. Chen, J. Mishler, S.C. Cho, X.C. Adroher, Appl. Energy 88 (2011) 9811007.

[3] A. El-kharouf, A. Chandan, M. Hattenberger, B.G. Pollet, J. Energy Inst. 85 (2012) 188-200.

[4] M. Miller, A. Bazylak, J. Power Sources 196 (2011) 601-613.

[5] N. Zamel, X. Li, Prog. Energy Combust. Sci. 37 (2011) 292-329.

[6] M.M. Mench, Fuel Cell Engines, John Wiley \& Sons, Inc., New Jersey, 2008.

[7] S.A. Bhat, J. Sadhukhan, AIChE J. 55 (2009) 408-422. 
[8] S. Adhikari, S. Fernando, Ind. Eng. Chem. Res. 45 (2006) 875-881.

[9] B.M. Besancon, V. Hasanov, R. Imbault-Lastapis, R. Benesch, M. Barrio, M. J. Mølnvik, Int. J. Hydrogen Energy 34 (2009) 2350-2360.

[10] A.A. Franco, in: C. Hartnig, C. Roth (Eds.), Polymer Electrolyte Membrane and Direct Methanol Fuel Cell Technology, Woodhead Publishing Ltd., Cambridge, 2012, pp. 291-367.

[11] H.A. Gasteiger, J.E. Panels, S.G. Yan, J. Power Sources 127 (2004) 162-171.

[12] M.K. Debe, Nature 486 (2012) 43-51.

[13] Y. Hashimasa, Y. Matsuda, M. Akai, in: ECS Trans, 2010, p. 131.

[14] M. Angelo, K. Bethune, R. Rocheleau, ECS Trans. 28 (2010) 169-181.

[15] M. Angelo, J. St-Pierre, K. Bethune, R. Rocheleau, ECS Trans. 35 (2011) 167-178.

[16] J.X. Zhang, T. Thampan, R. Datta, J. Electrochem. Soc. 149 (2002) A765-A772.

[17] D. Imamura, D. Ebata, Y. Hashimasa, M. Akai, S. Watanabe, SAE Paper 2007-012010, 2007.

[18] G. Bender, M. Angelo, K. Bethune, S. Dorn, T. Thampan, R. Rocheleau, J. Power Sources 193 (2009) 713-722.

[19] G. Bender, M. Angelo, K. Bethune, R. Rocheleau, J. Power Sources 228 (2013) 159.

[20] T.V. Reshetenko, K. Bethune, R. Rocheleau, J. Power Sources 218 (2012) 412-423.

[21] T. Murahashi, T. Mitsumoto, E. Nishiyama, ECS Trans. 25 (2009) 869-879.

[22] A. Rabbani, M. Rokni, Appl. Energy 111 (2013) 1061-1070.

[23] D.J.L. Brett, P. Aguiar, N.P. Brandon, A.R. Kucernak, Int. J. Hydrogen Energy 32 (2007) 863-871.

[24] C. Bonnet, L. Franck-Lacaze, S. Ronasi, S. Besse, F. Lapicque, Chem. Eng. Sci. 65 (2010) 3050-3058.

[25] R.K. Ahluwalia, X. Wang, J. Power Sources 177 (2008) 167-176.

[26] S. Zhai, P. Sun, F. Chen, S. Zhou, C. Zhang, Int. J. Hydrogen Energy 35 (2010) 87728782.

[27] M. Cordner, M. Matian, G.J. Offer, T. Hanten, E. Spofforth-Jones, S. Tippetts, A. Agrawal, L. Bannar-Martin, L. Harito, A. Johnson, R. Clague, F. Marquis, A. Heyes, Y. Hardalupas, N.P. Brandon, J. Power Sources 195 (2010) 7838-7848.

[28] B. Wu, M. Matian, G.J. Offer, Int. J. Low Carbon Technol. 7 (2012) 28 e37. 
[29] R.K. Ahluwalia, X. Wang, J. Kwon, A. Rousseau, J. Kalinoski, B. James, J. Marcinkoski, J. Power Sources 196 (2011) 4619-4630.

[30] R.K. Ahluwalia, X. Wang, J. Power Sources 180 (2008) 122-131.

[31] H. Karimäki, L.C. Pérez, K. Nikiforow, T.M. Keränen, J. Viitakangas, J. Ihonen, Int. J. Hydrogen Energy 36 (2011) 10179-10187.

[32] L.C. Pérez, J. Ihonen, J.M. Sousa, A. Mendes, Fuel Cells 13 (2013) 203-216.

[33] Y. Matsuda, Y. Hashimasa, D. Imamura, M. Akai, S. Watanabe, Rev. Automot. Eng. 30 (2009) 167.

[34] M.V.S. Alvarez, in: ETH/PSI, Zürich, 2006.

[35] L.C. Pérez, T. Rajala, J. Ihonen, P. Koski, J.M. Sousa, A. Mendes, Int. J. Hydrogen Energy 38 (2013) 16286-16299.

[36] J. Zhang, R. Datta, Electrochem. Solid-State Lett. 6 (2003) A5-A8.

[37] C.-Y. Chen, W.-H. Lai, W.-M. Yan, C.-C. Chen, S.-W. Hsu, J. Power Sources 243 (2013) 138-146.

[38] J. St-Pierre, Y. Zhai, M. Angelo, Int. J. Hydrogen Energy 37 (2012) 6784-6789.

[39] L.-Y. Sung, B.-J. Hwang, K.-L. Hsueh, W.-N. Su, C.-C. Yang, J. Power Sources 242 (2013) 264-272.

[40] in.

[41] W. Wang, J. Power Sources 191 (2009) 400-406.

[42] K.K. Bhatia, C.-Y. Wang, Electrochim. Acta 49 (2004) 2333-2341.

[43] H.S. Chu, C.P. Wang, W.C. Liao, W.M. Yan, J. Power Sources 159 (2006) 10711077.

[44] C.-P. Wang, H.-S. Chu, J. Power Sources 159 (2006) 1025-1033.

[45] N. Zamel, X.G. Li, Int. J. Hydrogen Energy 33 (2008) 1335-1344.

[46] T. Tingelöf, L. Hedström, N. Holmström, P. Alvfors, G. Lindbergh, Int. J. Hydrogen Energy 33 (2008) 2064e2072.

[47] L.C. Pérez, L. Brandão, J.M. Sousa, A. Mendes, Renewable Sustainable Energy Rev. 15 (2011) 169-185.

[48] W. Vielstich, in: W. Vielstich, A. Lamm, H.A. Gasteiger (Eds.), Handbook of Fuel Cells, John Wiley \& Sons, Ltd., New Jersey, 2010.

[49] A.A. Franco, M. Guinard, B. Barthe, O. Lemaire, Electrochim. Acta 54 (2009) 52675279.

[50] N. Möller, S.O. Hansson, Reliab. Eng. Syst. Saf. 93 (2008) 798-805. 